Pinus sylvestris and Equisetum arvense were chosen as well-known examples of the Bryophyta, Thallophyta, Gymnospermae and Pteridophyta respectively. We have also obtained qualitative results on Lolium italicum which agree closely with those of Synge ${ }^{3}$ on L. perenne, and on Medico sativa agreeing with those of Vickerey ${ }^{4}$, who used standard chemical methods of analysis.

$E$. arvense has also been examined at regular intervals throughout the development of the sporophyte generation.

Work on these and related lines is being actively pursued.

Technical College, Sunderland.

\section{K. MANSFORD}

R. RAPER

King's College, Newcastle upon Tyne. June 2.

${ }^{1}$ Coulson, Chem. and Indust., 971 (1953). Duvic, Amer. J. Bot., 39,658 (1952). Miettinen and Virtanen, Physiol. Plant., 5, $540(1952)$ and Berner, Ann. Bot., 18, 15 (1954).

${ }^{2}$ Nature, 170, 660 (1951).

siochem. J., 49, 642 (1951).

4 Yearbook of the Carnegie Inst. of Washington, 29, 349.

\section{Occurrence of Falkenbergia rufolanosa in the Isle of Man}

Since the reports by de Valera ${ }^{1}$, Harvey and Drew $^{2}$, and Drew ${ }^{3}$ of the occurrence of Asparagopsis armata Harv, and what is believed to be another phase of its life-history, Falkenbergia rufolanosa in a number of localities in Ireland and on the southwest coast of England, its spread around the British coast has been watched with interest by phycologists. A spread eastwards along the south coast was reported by Kerslake ${ }^{4}$ in September 1953 when Asparagopsis armata was found on Wembury Beach.

During the course of a survey of an area in and around the harbour at Port St. Mary, Isle of Man, by a party of students from the University of Liverpool and Royal Holloway College, London, at the end of March, Falkenbergia rufolanosa was found in great quantity floating in the water in the harbour at low tide, and both floating and attached to other seaweeds in pools in various positions on the shore. This is the first record for the plant in the Isle of Man, and it is of interest that it should appear in abundance, first of all, in one of the functioning harbours and one used by coastal vessels. A search of the shores near by indicated that it had, as yet, spread very little from the harbour, though the spread had obviously begun; it was found growing attached in a few pools on the outer side of the breakwater, and one can perhaps assume that its spread around the Island is only a matter of time. I Of all the material examined, none was found to be reproducing.

It will be of interest to see whether the invasion of the Isle of Man by Falkenbergia is followed, as it has been in other places, by Asparagopsis armata.

\section{I. WALKER}

E. M. Burrows

Hartley Botanical Laboratories,

$$
\text { S. M. LODGE }
$$

\section{Use of Glutamine by the Mammary Gland for the Synthesis of Casein}

IN continuation of earlier work on casein synthesis ${ }^{1}$, further experiments have aimed at determining which components, taken from the blood-stream by the mammary gland, provide the glutamic acid of casein.

$1{ }^{14} \mathrm{C}$ DL-glutamine was injected intravenously into a lactating goat and specific activities were measured in various components of blood and milk taken at intervals up to $12 \mathrm{hr}$. after injection. During the first few hours the specific activity of the free glutamine of plasma remained many times that of both the free glutamic acid and the glutamic acid of plasma proteins. This difference is illustrated (Table 1) by the specific activities in blood taken at $3 \mathrm{hr}$. after injection; in samples taken at $20 \mathrm{~min}$. and $1 \mathrm{hr}$. the specific activities of glutamine were higher than at $3 \mathrm{hr}$. while those of free glutamic acid and plasma protein glutamic acid were approximately the same or lower.

Table 1. Specific Activities in Blood and Mrlk SAMples taken AT 3 HR. AFTER INJECTING $1{ }^{14} \mathrm{C}$ DL-GLUTAMINE (425 MGM. : $38.0 \mu \mathrm{C}$.) $(\mu \mathrm{c} . / \mathrm{m} . \mathrm{mol}$. carbon in carbon No. 1)

\begin{tabular}{|c|c|c|c|}
\hline \multicolumn{2}{|c|}{ Blood plasma } & \multicolumn{2}{|l|}{ Milk } \\
\hline Free glutamine & $117 \times 10^{-3}$ & $\begin{array}{l}\text { Casein glutamine } \\
\text { (a) }\end{array}$ & $143 \times 10^{-3}$ \\
\hline $\begin{array}{l}\text { Free glutamic } \\
\text { acid }\end{array}$ & $27 \cdot 2 \times 10^{-3}$ & $\begin{array}{l}\text { Casein glutamic } \\
\text { acid }(a)\end{array}$ & $<25 \times 10^{-3}$ \\
\hline $\begin{array}{l}\text { Plasina protein } \\
\text { glutimic acid }\end{array}$ & & $\begin{array}{l}\text { Total glutamic } \\
\text { acid of casein }(b)\end{array}$ & $122 \times 10^{-3}$ \\
\hline
\end{tabular}

(a) After enzymatic hydrolysis. (b) After acid hydrolysis.

Casein samples were hydrolysed in two ways: by heating with hydrochloric acid and by incubating with a pancreas suspension. The specific activity of glutamic acid in each acid hydrolysate was measured, and glutamine and glutamic acid were isolated from each pancreas hydrolysate and their specific activities also measured. The first milk sample was taken at $1.5 \mathrm{hr}$.; the specific activities found in the casein of the second milk sample taken at $3 \mathrm{hr}$. are shown in Table 1 . It is seen that the specific activity of casein glutamine is slightly higher than that of the free glutamine of plasma at $3 \mathrm{hr}$., while that of casein glutamic acid is much lower. The results suggest that those residues which are present in casein as glutamine are derived largely from the free glutamine of plasma, and those present as glutamic acid are derived from some other source.

To confirm that the free glutamine of plasma is directly incorporated into casein, $\left(1-{ }^{14} \mathrm{C}: \operatorname{amide}{ }^{15} \mathrm{~N}\right)$ DL-glutamine was injected intravenously into the goat and milk taken at $1.5 \mathrm{hr}$. after injection. It is seen in Table 2 that, as expected, the ratio $(\mu \mathrm{c} / \mathrm{m}$. mol. carbon : atoms per cent excess ${ }^{15} \mathrm{~N}$ ) in the glutamine

Table 2. (1-14 $\mathrm{C}:$ AMIDH-16 $\mathrm{N}$ ) DL-GLUTAMINE (563 MGM.) INJEOTED AND

\begin{tabular}{|c|c|c|c|}
\hline & $\begin{array}{l}\text { Atoms } \% \\
\text { excess } 15\end{array}$ & $\begin{array}{l}\mu \mathrm{c} . / \mathrm{m} . \mathrm{mol} . \\
\text { carbon in car- } \\
\text { bon No. } 1\end{array}$ & $\frac{\mu \mathrm{c} . / \mathrm{m} . \mathrm{mol} \text {. carbon }}{\text { Atoms } \% \text { excess }{ }^{15} \mathrm{~N}}$ \\
\hline $\begin{array}{l}\text { Injected gluta- } \\
\text { mine } \\
\text { Casein gluta- } \\
\text { mine } \mathrm{N} \text { of } \\
\text { Amide } \mathrm{c}(a) \\
\text { casein }(a) \\
\text { Non-amide } \mathrm{N} \\
\text { of casein }(b)\end{array}$ & $\begin{array}{l}25.8 \\
0.611 \\
0.444 \\
0.004\end{array}$ & $\begin{array}{c}1,800 \times 10^{-3} \\
30 \cdot 6 \times 10^{-3} \\
- \\
-\end{array}$ & $\begin{array}{c}69 \cdot 8 \times 10^{-3} \\
50 \cdot 1 \times 10^{-3} \\
\ldots \\
-\end{array}$ \\
\hline
\end{tabular}

(a) Nitrogen released as ammonia on acid hydrolysis. (b) Nitrogen not released as ammonia on acid hydrolysis. 